\title{
Knowledge, Attitudes and Practices Related to Dietary Supplements among a Group of Palestinian Pharmacists
}

\author{
"Mohammad Altamimi, ${ }^{1}$ May Hamdan, ${ }^{2}$ Manal Badrasawi, ${ }^{1}$ Saad Allahham ${ }^{3}$
}

\begin{abstract}
ABSTRAC T: Objectives: The use of dietary supplements (DS) has increased, but due to a lack of related regulations, the prescription of DS depends on pharmacists' knowledge. Hence, this study aimed to evaluate the knowledge, attitudes and practices (KAP) related to DS among community-based pharmacists. Methods: This study followed a crosssectional design targeting community pharmacists in West Bank, Palestine between September and December 2019. Selected participants filled a self-administered questionnaire regarding their KAP related to DS. The questionnaire contained 15 items: five questions on knowledge, seven on practices and three on attitudes. Results: At a 90\% response rate, $56.2 \%$ of the representative sample was female. The participants' experience was distributed almost equally across the categories of $0-5,5-10$ and over 10 years. Additionally, a majority of the participants were the responsible pharmacist and/or the pharmacy owner. Overall, the participants showed a moderate level of knowledge about DS with a mean score of $3.68 \pm 1.1$ out of 5 ; the correct answers ranged from $3.6 \%$ to $75.3 \%$ of the surveyed participants. The practices with the highest frequencies were as follows: taking DS sometimes (79.9\%), taking supplements from wellknown brands (56.2\%), giving supplements to any patient (55.7\%), selling supplements according to the participants' knowledge (74.2\%) and providing advice about supplements (73.2\%). The questions about the pharmacists' attitudes towards DS market regulation revealed that more than half (52\%) of the participants believed that it was suitable. The association between knowledge score and practices was highly significant $(P<0.001)$. Conclusion: The study revealed that participants had moderate knowledge about DS. Additionally, knowledge and practices were highly connected.
\end{abstract}

Keywords: Dietary Supplements; Pharmacists; Knowledge; Attitude; General Practice; Curriculum.

\author{
Advances IN KNOWLedge \\ To the authors' knowledge, this is the first study in Palestine to highlight the knowledge, attitudes and practices (KAP) related to dietary \\ supplements (DS) amongst pharmacists. \\ The study evaluated the knowledge and practices of the pharmacists, which was revealed to be moderate. \\ The study helped to identify the gap in the KAP of pharmacists as frontline healthcare providers and suggested solutions to bridge such \\ a gap.

\section{Application to Patient Care} \\ Addressing such a gap in the knowledge, attitudes and practices of pharmacists will positively improve the service provided to patients \\ who use DS.
}

\section{$\mathrm{T}$} HEORETICALLY, DIETARY SUPPLEMENTS (DS) are seen as isolated and highly concentrated forms of nutrients and other substances such as herbs and botanicals, sport and weight-loss supplements and meal replacements. ${ }^{1,2}$ They are consumed in the form of pills, capsules, powders or liquids that are designed to be taken in doses supplementing a diet. DS were conventionally used to compensate for a low-nutrient diet or, at least, provide an easier way to stay healthy. ${ }^{1}$ In developed countries, the number of adults using multivitamins or mineral supplements is increasing (more than 60\% of adults), especially in the age group of over 60 years. ${ }^{1}$ It was estimated that in 2018, $\$ 30.7$ billion was spent on vitamins and nutritional supplements in the USA alone. ${ }^{3,4}$ Another study showed that approximately one-third of the adolescents included in the study were using supplements; almost half of them were taking them on a daily basis. ${ }^{3}$ Almost half of the population of the UK was also reported to be using DS. ${ }^{4}$ Moreover, parents who use supplements are more likely to use them for their infants and toddlers (age 4-24 months). Briefel et al. estimated that the prevalence of DS use was $19 \%$ among infants. ${ }^{2}$

Research has shown that several factors have led individuals to take DS: maintaining health and wellbeing, providing the body with nutrients that are deficient in the food and improving cognitive and physical performance. ${ }^{5,6}$ A positive belief regarding DS is common among individuals in these categories. For example, the following views were expressed by many DS users: 'the best I can do for myself', 'help me to be 
healthy' and 'the easy way to stay healthy?? It is critical to mention here that DS intake is associated with other factors such as gender, age, level of education, socioeconomic status, place of residence and ethnicity. ${ }^{5,6}$

Previous studies have demonstrated that DS can help in reducing micronutrient deficiencies. ${ }^{1}$ However, more recent studies have revealed a prevalence of overconsumption [exceeding the tolerable upper intake level (UL)] of minerals/vitamins as a result of DS intake in the general population as well as among individuals of specific nutrition and health status, e.g. athletes, adolescents and obese individuals. ${ }^{1,3}$ Therefore, the increasing rate of DS consumption is not necessarily proportionate to the population's needs and the level of over-dosing amongst the wider population remains high. ${ }^{7}$ Blumberg et al. noticed that multivitamin/multimineral use at any frequency was linked to a lower prevalence of inadequacy $(P<0.01)$ for 15 out of the 17 nutrients examined. ${ }^{8}$ Furthermore, there has been an increased prevalence of intakes greater than the UL for nutrients especially when the supplements provide the recommended daily requirement or above. ${ }^{9}$

Similarly, it was reported that regular users of DS are people who are concerned about their health. ${ }^{4}$ Such people are found to have higher intakes of fruits and vegetables than non-users, which may make those people prone to overconsumption of minerals/ vitamins and toxicity. ${ }^{10}$

It is also worth mentioning that DS intake can be regulated personally without the supervision of healthcare professionals (e.g. nutritionist, dietitian and general practitioner). ${ }^{6}$

In the Middle East, micronutrient deficiencies are becoming a public concern, particularly amongst children and women of childbearing age. ${ }^{11,12}$

One-third of the population, in this particular area, are iron and iodine-deficient; $50 \%$ of the people are dyslipidaemic, and $65 \%$ are overweight or obese. ${ }^{13}$

Despite various recommendations indicating the importance of a well-balanced diet with fruits and vegetables to meet the micronutrient and fibre requirements, the achievement of such a goal is relatively low. The long-term consequences can be dysfunctionality in the cellular system and chronic diseases. ${ }^{10}$ Using multivitamins can also be associated with a decrease in the risk of chronic disease, as shown by some studies. ${ }^{4,14,15}$ Therefore, it is expected that more people in the Middle East are going to use DS.

In many countries, DS use is not subject to specific regulations and they can be sold over the counter. ${ }^{16}$ It is well-known that DS, primarily herbal, may interact with other prescribed drugs. ${ }^{17}$ However, it was reported that in the USA, individuals who have been prescribed drugs for chronic diseases also take DS. ${ }^{16}$ This emphasises the fact that pharmacists' knowledge and practices regarding DS are crucial. As DS are widely sold in community pharmacies, pharmacists have the opportunity to provide DS users with advice and discuss different choices. However, due to no or insufficient knowledge, whether such conversations happen between the pharmacist and consumer is doubtful.

Studies have highlighted that community pharmacists have poor knowledge of dietary and herbal supplements. ${ }^{17-19}$ However, pharmacists seem to insist on contributing to a patient's requirements of the DS. ${ }^{5}$ Reportedly, community pharmacists appear to rarely use reliable references that were part of the pharmacy curriculum. .,14 $^{2}$

Pharmacists serving the frontline of the healthcare practitioners are required to be equipped with knowledge about DS alongside possible drug interactions. They are also required to provide their patients with an unbiased, evidence-based opinion about the healthy use of DS. ${ }^{19}$ It was reported that in countries such as Palestine, Qatar, Kuwait, Jordan and Iran, DS are one of the most recommended complementary alternative medicines suggested by pharmacists. ${ }^{19-22}$ In the Palestinian context, for example, DS are taken by around $12 \%$ of polypharmacy patients who simultaneously take other medications. ${ }^{23}$ Therefore, the risk of a pharmacokinetic or pharmacodynamic interaction between drugs and DS is high amongst this group. ${ }^{15}$ Such interaction is a huge concern, especially with certain DS that contain pharmaceutical contaminants. ${ }^{5}$ Therefore, as many studies have highlighted, there is an urgent need for pharmacists to accrue proper knowledge of DS and, more importantly, offer better professional medical advice and guidance to patients. ${ }^{24,25}$

The available literature revealed that there is a paucity of research in the field, specifically on the level of knowledge. DS-related practices of community pharmacists in Palestine requires further exploration. Therefore, this study aimed to evaluate the knowledge, attitudes and practices (KAP) concerning DS and create a link between knowledge and practices among community pharmacists in the West Bank, Palestine.

\section{Methods}

A cross-sectional survey was conducted between September and December 2019 in the northern and southern districts of the West Bank, Palestine; Jenin, Tubas, Nablus and Tulkarem in the north and Hebron in the south. The included pharmacies were either public or non-governmental. The number of samples 
and distribution was based on the latest information published by the Ministry of Health, ${ }^{26}$ particularly in the northern districts, Jenin and Tubas have 148, Nablus and Salfit have 201 and Tulkarem and Qalqilia have 136, while in the southern district, Hebron has 244 community pharmacies. It was reported that the total number of licensed community pharmacies in the West Bank is about 1,101 by the year $2020 .^{26}$

A total of 252 questionnaires were distributed. 227 completed questionnaires were returned, yielding a $90 \%$ response rate. The rest of the questionnaires either had missing data or had not been filled in properly. The following percentages of coverage were achieved: 100 questionnaires from the northern districts (representing 20.6\% of pharmacies in that area) and 127 questionnaires from the southern districts (representing $52 \%$ of pharmacies in that area).

The questionnaire, comprising of two parts, was adopted from the literature with modifications to suit the aim of the study. The first part was about personal and sociodemographic information, including gender, age, residency, work position, experience, marital status and health status, while the second part was about knowledge, attitudes and practices. The knowledge part of this section consisted of five questions: 'Do you understand the term DS?'; 'Can you identify the type of DS?'; 'Can you define DS?'; 'What is your source of knowledge about DS?'; and 'What is your knowledge about the treatment of nutrient deficiency?' The seven questions regarding practices included those on taking DS, giving DS, recommending DS, who DS should be prescribed to and who should prescribe DS. In the attitudes part of this section, there were three questions, including those regarding the following: the reason a person took DS, whether pharmacists were qualified to prescribe DS and regulations of DS.

For scoring, the following scale was used, where a correct answer in the knowledge and practices sections was given one point, while an incorrect answer was given zero points. The knowledge scale ranged from 0 to 5 (poor knowledge was 0-2, medium knowledge was 3 and knowledgeable was 4-5), and for practices it ranged from 0 to 7 (poor practice was $<3$, satisfactory practice was $4-5$ and good practice was $6-7$ ). The views on the DS market were used to measure the attitudes of the participants.

The Statistical Package for the Social Sciences (SPSS), Version 21.0 (IBM Corp., Armonk, New York, USA) was used to analyse the collected data; the selection of statistical tests according to variables types was done following Field's work. ${ }^{27}$

The reliability test for the knowledge items showed that Cronbach's alpha was 0.71, while for practice items, it was 0.65 , revealing acceptable reliability. The normality test was done for nutritional knowledge scores using the Kolmogorov Simonov test. Descriptive statistics, including the means and standard deviations, were used along with the interval data of the continuous dependent and independent variables and the percentages were used with the categorical variables. An Independent t-test and oneway ANOVA tests were conducted to examine the relationship between the sociodemographic variables, the practices variables and the total score of the knowledge items at $P<0.05$.

This study was approved by the institutional review board at An-Najah National University and was assigned the number 12 . Direct verbal consent was provided by each subject before filling the questionnaire and participation was completely voluntary without any monetary or non-monetary incentives. No names of participants were mentioned during data extraction and the raw data were solely used for research and not shared with a third party.

\section{Results}

The total number of pharmacists who joined the study was 227; only 194 participants were included in the final analysis as 33 participants were excluded due to missing data. Table 1 shows the demographic characteristics of the study participants (presented as frequencies and percentages). The difference in the number of male and female participants was small (56.2\% female and $43.8 \%$ male) and $67.1 \%$ of the participants were married. A majority of the participants were living in cities (76.3\%). With regard to work position, $54.1 \%$ were employed as 'responsible pharmacists.' Experience wise, $37.1 \%$ of the participants had less than 5 years of experience, $29.4 \%$ had $5-10$ years of experience and $33.5 \%$ had more than 10 years of experience.

Table 2 shows participants' knowledge about DS. Overall, participants indicated a moderate level of knowledge regarding DS; the mean score was 3.68 \pm 1.1 . The range of the correct answers was from $3.6 \%$ (as in item 5) to $75.3 \%$ (as in item 2).

Table 3 shows the participants' practices and attitudes towards using supplements (presented as frequencies and percentages). The major practices with a high frequency were as follows: taking supplements sometimes (79.9\%), taking supplements from well-known brands (56.2\%), giving supplements to any patient $(55.7 \%)$, selling supplements according to their knowledge (74.2\%) and providing advice about supplements (73.2\%). The questions about the pharmacists' attitudes towards the prescription, recommendation and regulation of the DS market 
Table 1: Sociodemographic characteristics of pharmacists from the West Bank, Palestine $(\mathrm{N}=194)$

\begin{tabular}{|c|c|c|c|}
\hline Variable & & $\mathbf{n}$ & Percentage \\
\hline \multirow[t]{2}{*}{ Gender } & Male & 85 & 43.8 \\
\hline & Female & 109 & 56.2 \\
\hline \multirow[t]{4}{*}{ Age (in years) } & $23-28$ & 113 & 58.2 \\
\hline & $29-33$ & 3 & 1.5 \\
\hline & $34-39$ & 33 & 17.0 \\
\hline & $>40$ & 45 & 23.2 \\
\hline \multirow[t]{4}{*}{ Marital status } & Married & 49 & 25.3 \\
\hline & $\begin{array}{l}\text { Married } \\
\text { with } \\
\text { children }\end{array}$ & 81 & 41.8 \\
\hline & Single & 64 & 33.0 \\
\hline & Other & 0 & 0.0 \\
\hline \multirow[t]{2}{*}{ Area of residence } & City & 148 & 76.3 \\
\hline & $\begin{array}{l}\text { Village/ } \\
\text { camps }\end{array}$ & 46 & 23.7 \\
\hline \multirow[t]{3}{*}{ Work position } & $\begin{array}{l}\text { Responsible } \\
\text { pharmacist }\end{array}$ & 105 & 54.1 \\
\hline & $\begin{array}{c}\text { Assistant } \\
\text { pharmacist }\end{array}$ & 32 & 16.5 \\
\hline & $\begin{array}{c}\text { Pharmacy } \\
\text { owner }\end{array}$ & 57 & 29.4 \\
\hline \multirow[t]{3}{*}{ Years of experience } & Less than 5 & 72 & 37.1 \\
\hline & $5-10$ & 57 & 29.4 \\
\hline & $\begin{array}{c}\text { More than } \\
10\end{array}$ & 65 & 33.5 \\
\hline \multirow[t]{2}{*}{ Chronic disease } & No & 179 & 92.3 \\
\hline & Yes & 15 & 7.7 \\
\hline
\end{tabular}

Table 2: Knowledge of pharmacists with regard to dietary supplements in the West Bank, Palestine $(\mathrm{N}=194)$

\begin{tabular}{|c|c|c|c|}
\hline $\begin{array}{l}\text { Item } \\
\#\end{array}$ & Item & $\begin{array}{c}\text { Correct } \\
\text { answer } \\
\text { n (\%) }\end{array}$ & $\begin{array}{c}\text { Wrong } \\
\text { answer } \\
\mathrm{n}(\%)\end{array}$ \\
\hline 1 & $\begin{array}{l}\text { Understanding the } \\
\text { meaning of the term DS }\end{array}$ & $65(33.5)$ & $\begin{array}{l}129 \\
(66.5)\end{array}$ \\
\hline 2 & Identifying the type of DS & $\begin{array}{c}146 \\
(75.3)\end{array}$ & $\begin{array}{c}48 \\
(24.7)\end{array}$ \\
\hline 3 & Definition of DS & $51(26.3)$ & $\begin{array}{c}143 \\
(73.7)\end{array}$ \\
\hline 4 & $\begin{array}{l}\text { Source of knowledge about } \\
\text { DS* }\end{array}$ & $\begin{array}{l}117 \\
(60.3)\end{array}$ & $\begin{array}{c}77 \\
(39.7)\end{array}$ \\
\hline 5 & $\begin{array}{l}\text { Methods of treating } \\
\text { nutrient deficiency }\end{array}$ & $7(3.6)$ & $\begin{array}{l}187 \\
(96.4)\end{array}$ \\
\hline
\end{tabular}

DS = dietary supplement

*This item was assessed according to the reliability of the sources.
Table 3: Practices and attitudes of pharmacists with regard to dietary supplements in the West Bank, Palestine $(\mathrm{N}=194)$

\begin{tabular}{|c|c|c|}
\hline Item & Answers & $\mathrm{N}(\%)$ \\
\hline \multirow[t]{3}{*}{ I take DS } & Never & $\begin{array}{c}21 \\
(10.8)\end{array}$ \\
\hline & Sometimes* & $\begin{array}{c}155 \\
(79.9)\end{array}$ \\
\hline & Often $^{\dagger}$ & $\begin{array}{l}18 \\
(9.3)\end{array}$ \\
\hline \multirow[t]{3}{*}{ I take DS if } & $\begin{array}{l}\text { The brand is familiar, well } \\
\text { known or trusted }\end{array}$ & $\begin{array}{c}109 \\
(56.2)\end{array}$ \\
\hline & $\begin{array}{l}\text { The price is reasonable, it } \\
\text { is within my budget or it } \\
\text { is free }\end{array}$ & $\begin{array}{c}32 \\
(16.5)\end{array}$ \\
\hline & $\begin{array}{l}\text { The ingredients are high in } \\
\text { concentration }\end{array}$ & $\begin{array}{c}53 \\
(27.3)\end{array}$ \\
\hline \multirow[t]{3}{*}{$\begin{array}{l}\text { Usually, I give } \\
\text { DS to }\end{array}$} & $\begin{array}{l}\text { Any customer who buys } \\
\text { them }\end{array}$ & $\begin{array}{c}36 \\
(18.6)\end{array}$ \\
\hline & $\begin{array}{l}\text { Any patient who requires } \\
\text { them }\end{array}$ & $\begin{array}{c}108 \\
(55.7)\end{array}$ \\
\hline & $\begin{array}{l}\text { Anyone referred by a } \\
\text { physician }\end{array}$ & $\begin{array}{c}50 \\
(25.8)\end{array}$ \\
\hline \multirow[t]{3}{*}{$\begin{array}{l}\text { I sell DS according } \\
\text { to }\end{array}$} & $\begin{array}{l}\text { Availability: whatever I } \\
\text { have in my pharmacy }\end{array}$ & $35(18)$ \\
\hline & $\begin{array}{l}\text { My knowledge about the } \\
\text { quality of product, source, } \\
\text { etc. }\end{array}$ & $\begin{array}{c}144 \\
(74.2)\end{array}$ \\
\hline & Price of the product & $\begin{array}{c}15 \\
(7.7)\end{array}$ \\
\hline \multirow{3}{*}{$\begin{array}{l}\text { If a patient asks } \\
\text { for advice about } \\
\text { DS, I }\end{array}$} & $\begin{array}{l}\text { Redirect them to the } \\
\text { physician }\end{array}$ & $\begin{array}{c}20 \\
(10.3)\end{array}$ \\
\hline & $\begin{array}{l}\text { Redirect them to the } \\
\text { nutritionist }\end{array}$ & $\begin{array}{c}32 \\
(16.5)\end{array}$ \\
\hline & $\begin{array}{l}\text { Provide advice based on } \\
\text { what I know }\end{array}$ & $\begin{array}{c}142 \\
(73.2)\end{array}$ \\
\hline \multirow{3}{*}{$\begin{array}{l}\text { DS should be } \\
\text { prescribed by }\end{array}$} & Anyone, with no restriction & $8(4.1)$ \\
\hline & Specialised persons & $\begin{array}{l}161 \\
(83)\end{array}$ \\
\hline & Pharmacists only & $\begin{array}{c}25 \\
(12.9)\end{array}$ \\
\hline \multirow[t]{3}{*}{$\begin{array}{l}\text { I recommend the } \\
\text { use of DS to }\end{array}$} & Everyone & $\begin{array}{c}34 \\
(17.5)\end{array}$ \\
\hline & Persons who need them & $\begin{array}{c}158 \\
(81.4)\end{array}$ \\
\hline & No one & $2(1)$ \\
\hline \multirow{3}{*}{$\begin{array}{l}\text { In Palestine, the } \\
\text { regulations on } \\
\text { exporting and } \\
\text { importing } \\
\text { DS, etc., are }\end{array}$} & Suitable & $\begin{array}{c}102 \\
(52.6)\end{array}$ \\
\hline & Very restrictive & $\begin{array}{c}45 \\
(23.2)\end{array}$ \\
\hline & Very flexible & $\begin{array}{c}47 \\
(24.2)\end{array}$ \\
\hline
\end{tabular}

$D S=$ dietary supplements.

*Less than 3 times a month; ${ }^{\dagger}$ Once to twice a week. 
Table 4: Relationship between knowledge score and various sociodemographic variables of pharmacists with regard to dietary supplements in the West Bank, Palestine $(\mathrm{N}=194)$

\begin{tabular}{|c|c|c|c|c|}
\hline Variable & & Mean & SD & $\begin{array}{c}P \\
\text { value }\end{array}$ \\
\hline \multirow[t]{2}{*}{ Gender } & Male & 3.68 & 1.1 & \multirow{2}{*}{$0.939^{*}$} \\
\hline & Female & 3.67 & 1.1 & \\
\hline \multirow{4}{*}{$\begin{array}{l}\text { Age } \\
\text { (in years) }\end{array}$} & $23-28$ & 3.69 & 1.01 & \multirow{4}{*}{$0.499^{+}$} \\
\hline & $29-33$ & 3.67 & 2.1 & \\
\hline & $34-39$ & 3.42 & 1.3 & \\
\hline & More than 40 & 3.8 & 1.2 & \\
\hline \multirow{3}{*}{$\begin{array}{l}\text { Marital } \\
\text { status }\end{array}$} & Married & 3.53 & 1.2 & \multirow{3}{*}{$0.589^{\dagger}$} \\
\hline & $\begin{array}{l}\text { Married with } \\
\text { children }\end{array}$ & 3.73 & 1.3 & \\
\hline & Single & 3.7 & 0.9 & \\
\hline \multirow{2}{*}{$\begin{array}{l}\text { Area of } \\
\text { residence }\end{array}$} & City & 3.66 & 1.1 & \multirow{2}{*}{$0.839^{*}$} \\
\hline & Village/camps & 3.8 & 1.6 & \\
\hline \multirow[t]{3}{*}{$\begin{array}{l}\text { Work } \\
\text { position }\end{array}$} & $\begin{array}{l}\text { Responsible } \\
\text { pharmacist }\end{array}$ & 3.62 & 1.2 & \multirow{3}{*}{$0.14^{+}$} \\
\hline & $\begin{array}{c}\text { Assistant } \\
\text { pharmacist }\end{array}$ & 4.03 & 1.2 & \\
\hline & Pharmacy owner & 3.58 & 0.9 & \\
\hline \multirow{3}{*}{$\begin{array}{l}\text { Years of } \\
\text { experience }\end{array}$} & Less than 5 & 3.75 & 0.9 & \multirow{3}{*}{$0.567^{+}$} \\
\hline & $5-10$ years & 3.72 & 1.2 & \\
\hline & More than 10 & 3.55 & 1.3 & \\
\hline \multirow{2}{*}{$\begin{array}{l}\text { Presence } \\
\text { of } \\
\text { chronic } \\
\text { disease }\end{array}$} & No & 3.64 & 1.1 & \multirow[b]{2}{*}{$0.318^{*}$} \\
\hline & Yes & 4 & 0.9 & \\
\hline
\end{tabular}

showed that more than half (52\%) of the participants believed that it was suitable as a majority of them believed that DS should be prescribed by a specialist (83\%), recommended to people who need them (81.4\%) and regulated by the law as it is now (52.6\%).

Table 4 presents the relationship between the knowledge score and the sociodemographic variables. The results revealed no significant relationship between the knowledge score and the other variables, which was indicated by no significant differences between the means of the defined groups.

The relationship between the level of knowledge and the attitudes and practices regarding DS use is presented in Table 5. The results revealed a significantly higher knowledge score among those who take the supplements depending on DS price, a patient's need for supplements or a patient's reliance on a nutritionist referral to use the supplements. Meanwhile, a significantly lower score of knowledge was found
Table 5: Relationship between the level of knowledge and the practices and attitudes of pharmacists with regard to dietary supplements in the West Bank, Palestine $(\mathrm{N}=194)$

\begin{tabular}{|c|c|c|c|}
\hline Item & & $\begin{array}{l}\text { Mean } \\
\pm \text { SD }\end{array}$ & $P$ value \\
\hline \multirow[t]{3}{*}{ I take DS } & Never & $3.7 \pm 1.3$ & \multirow{3}{*}{0.789} \\
\hline & Sometimes & $3.7 \pm 1.1$ & \\
\hline & Often & $3.5 \pm 1.3$ & \\
\hline \multirow[t]{3}{*}{ I take DS if } & $\begin{array}{l}\text { The brand is familiar, } \\
\text { well known or trusted }\end{array}$ & $3.7 \pm 1.0$ & \multirow{3}{*}{$0.0001^{*}$} \\
\hline & $\begin{array}{l}\text { The price is } \\
\text { reasonable, it is } \\
\text { within my budget or } \\
\text { it is free }\end{array}$ & $4.5 \pm 1.1$ & \\
\hline & $\begin{array}{l}\text { The ingredients are } \\
\text { high in concentration }\end{array}$ & $3.2 \pm 1.1$ & \\
\hline \multirow[t]{3}{*}{$\begin{array}{l}\text { Usually, I } \\
\text { give DS to }\end{array}$} & $\begin{array}{l}\text { Any customer who } \\
\text { buys them }\end{array}$ & $\begin{array}{l}2.75 \pm \\
1.2\end{array}$ & \multirow{3}{*}{$0.0001^{*}$} \\
\hline & $\begin{array}{l}\text { Any patient who } \\
\text { requires them }\end{array}$ & $4.1 \pm 0.9$ & \\
\hline & $\begin{array}{l}\text { Anyone referred by a } \\
\text { physician }\end{array}$ & $3.4 \pm 0.9$ & \\
\hline \multirow[t]{3}{*}{$\begin{array}{l}\text { I sell DS } \\
\text { according } \\
\text { to }\end{array}$} & $\begin{array}{l}\text { Availability: whatever } \\
\text { I have in my } \\
\text { pharmacy }\end{array}$ & $3.0 \pm 1.4$ & \multirow{3}{*}{$0.0001^{*}$} \\
\hline & $\begin{array}{l}\text { My knowledge about } \\
\text { the quality of product, } \\
\text { source, etc. }\end{array}$ & $3.9 \pm 1$ & \\
\hline & Price of the product & $3.4 \pm 1.1$ & \\
\hline \multirow{3}{*}{$\begin{array}{l}\text { If a patient } \\
\text { asks for } \\
\text { advice } \\
\text { about DS, I }\end{array}$} & $\begin{array}{l}\text { Redirect them to the } \\
\text { physician }\end{array}$ & $3.3 \pm 1.1$ & \multirow{3}{*}{$0.0001^{*}$} \\
\hline & $\begin{array}{l}\text { Redirect them to the } \\
\text { nutritionist }\end{array}$ & $4.9 \pm 1.1$ & \\
\hline & $\begin{array}{l}\text { Provide advice based } \\
\text { on what I know }\end{array}$ & $3.5 \pm 0.9$ & \\
\hline \multirow{3}{*}{$\begin{array}{l}\text { DS } \\
\text { should be } \\
\text { prescribed } \\
\text { by }\end{array}$} & $\begin{array}{l}\text { Anyone, with no } \\
\text { restriction }\end{array}$ & $2.2 \pm 1.3$ & \multirow{3}{*}{$0.0001^{*}$} \\
\hline & Specialised persons & $3.9 \pm 1.0$ & \\
\hline & Pharmacists only & $2.9 \pm 1.0$ & \\
\hline \multirow{3}{*}{$\begin{array}{l}\text { I recom- } \\
\text { mend the } \\
\text { use of DS to }\end{array}$} & Everyone & $2.6 \pm 1.0$ & \multirow{3}{*}{$0.0001^{*}$} \\
\hline & $\begin{array}{l}\text { Persons who need } \\
\text { them }\end{array}$ & $3.9 \pm 1.0$ & \\
\hline & No one & $2.0 \pm 1.4$ & \\
\hline \multirow{3}{*}{$\begin{array}{l}\text { In Palestine, } \\
\text { the regula- } \\
\text { tions on exp- } \\
\text { orting and } \\
\text { importing } \\
\text { DS, etc., are }\end{array}$} & Suitable & $3.7 \pm 1.1$ & \multirow{3}{*}{0.745} \\
\hline & Very restrictive & $3.7 \pm 1.5$ & \\
\hline & Very flexible & $3.6 \pm 1.0$ & \\
\hline
\end{tabular}

among pharmacists who take the supplements according to the concentration of nutrients (3.2 vs 4.5) or reported that they provided supplements for any patients that required them. 


\section{Discussion}

Incorporation of healthy eating habits with sufficient nourishment as part of a busy modern lifestyle is not a simple task. Due to increasing awareness among individuals about wellbeing and counteracting sicknesses, the utilisation of DS has become widespread. Different research investigations have shown that awareness about nutrition is expanding among both the all-inclusive community and special groups such as athletes, individuals experiencing malignancy treatment, healthcare professionals and students. ${ }^{28,29}$

Recently, community pharmacists' knowledge of DS was reported to be relatively poor despite a professional responsibility to provide advice about DS to the public. ${ }^{22}$ Researchers found that $33.3 \%$ of Ethiopian pharmacists had poor knowledge about DS, while in other studies, the lack of knowledge ranged between $40-60 \%{ }^{25}$

Generally speaking, pharmacies, which are considered to be a significant cornerstone of the health framework, are in the right position to counsel clients with evidence-based data about DS. Pharmacists in the Palestinian community enjoy high social status. Being a pharmacist is considered to be one of the well-paid professions. Pharmacy programs are also highly selective and students are required to enrol in a comprehensive range of courses on pathology, pharmacognosy and ethics in pharmacology. Standardisation of students' knowledge about a specific topic by modifying or updating the curriculum is included as part of the university mission. This study aimed to shed light on one of the essential topics representing the overlap between pharmacy and nutrition, i.e. DS. Given the results, it seems that the current situation is not in the best interest of consumers and there is a gap that needs to be filled through further action from policymakers either at the university level or the pharmacist syndicate level. The current research covered the northern and southern districts of the West Bank with 227 participants representing $24 \%$ of the community pharmacies.

Concerning the knowledge of pharmacists about DS, this study found that one-third of the pharmacists understood the meaning of the term DS. Meanwhile, 75.3\% of them showed correct knowledge about the types of DS. However, only $26.3 \%$ of the pharmacists correctly defined the meaning of the term DS and less than $5 \%$ of them knew about the methods of treating nutrient deficiency. A previous study conducted in Palestine showed that pharmacists' knowledge of complementary alternative medicine (CAM) was 'fair to average', while their ability to answer patients' questions about CAM was 'inadequate. ${ }^{19}$ In a study conducted in Saudi Arabia, almost half of the participating pharmacists agreed on the importance of receiving more training and continuing education pertaining to herbal products. ${ }^{18}$ A finding from another study suggested that a majority of pharmacists exhibited poor professional practice with regard to DS despite having adequate knowledge and a positive attitude towards DS. ${ }^{25}$ Hence, a suggestion was made to emphasise teaching or training community pharmacists on how to critically evaluate the use, efficacy and safety of standard DS. Mehralian et al. conducted a similar survey in Tehran and found that $62 \%$ of the participating pharmacists had weak knowledge of DS.22 These results highlighted the need to increase the awareness among the pharmacists about DS. Moreover, another study revealed that people rely on pharmacists' knowledge about DS and pharmacists are in a good position to provide patients with evidence-based information about DS, 30 however, their knowledge has to be improved to enable them to perform such a task adequately.

On the other hand, the current findings showed that a little more than $10 \%$ of the pharmacists never took DS, less than $10 \%$ of them took supplements often and the rest took supplements only sometimes. This indicated that at some capacity, pharmacists were convinced that DS could help and support wellbeing. Such results were in accordance with other findings of several studies where almost half of the participants were found to consume DS. ${ }^{30-35}$ Moreover, Howard et al. found that participants who personally took DS and recommended DS were twice the number of pharmacists who did not take DS personally and recommended DS to patients. ${ }^{28}$

In the current study, differences in knowledge scores were not significant between participants who took supplements and those who did not. The main drive for the high scoring participants who took supplements was the price $(P<0.0001)$. Another study conducted by Shraim et al. revealed that adequate knowledge is positively linked with pharmacist's level of study with a master's degree reported having a higher knowledge score than pharmacists with a bachelor's degree. ${ }^{19}$ In the same context, another study by Alsayari et al. concluded that pharmacists have good knowledge about some dietary supplements (herbal medicines) although their experience ranged from 1-20 years. ${ }^{18}$ Furthermore, pharmacists aged between 20 and 29 years were found to have a higher knowledge score than older pharmacists. In the current study, a majority of the sample were adults between 23 and 28 years of age, indicating that they had $0-5$ years of experience. The aforementioned results may explain the moderate scores achieved by the participants. 
In the current study, $74.3 \%$ of the pharmacists prescribed DS to any customer or patient who asked for them. At the same time, only $25.3 \%$ of the pharmacists sold supplements to patients on the advice of a physician. Knowledge played a great role in such a decision as high-scoring pharmacists sold DS according to their knowledge about the product quality, not due to price or availability $(P<0.000)$. This reflected the ethical responsibilities of pharmacists, which entails offering advice based on scientific and verified information.

Moreover, the findings showed that $26.8 \%$ of the pharmacists tended to redirect patients to physicians or nutritionists, while around $74.2 \%$ of the pharmacists provided advice to patients according to their knowledge. Pharmacists whose knowledge scores were higher preferred to redirect patients to nutritionists or physicians rather than taking the responsibility of giving advice. Such a result emphasised the initial statement of this study about the necessity of increasing pharmacists' awareness and knowledge related to DS. Medhat et al. explored similar trends, where $59.2 \%$ of the pharmacists considered that supplements should be dispensed according to the nutritionist's or physician's prescription. ${ }^{36}$ Meanwhile, $69.3 \%$ of the pharmacists considered that supplements could be sold in the pharmacy under the pharmacist's supervision. ${ }^{36}$

Finally, approximately half of the pharmacists from the current study considered the Palestinian regulations for exporting and importing DS suitable. Meanwhile, $22.7 \%$ of the pharmacists considered the Palestinian regulations in this regard very restrictive, while a similar portion (23.7\%) of the pharmacists considered these regulations very flexible. Knowledge scores related to DS were similar among pharmacists with different attitudes towards the regulations, meaning that knowledge was not a significant player in taking such a decision.

The study has certain limitations with regard to sampling and design. First, as a cross-sectional study, there may be a bias from responders and data collectors. However, the sample was made as representative as possible. Secondly, the interpretation of relationships between the outcomes and the prevalence of KAP was not found to be easily generalisable.

\section{Conclusion}

The current study showed that a majority of the participants scored moderately in terms of knowledge related to DS. The low level of knowledge is likely to affect their practices in taking or giving DS. However, it was observed that this level of knowledge has no relationship with their attitude towards DS regulations. This emphasised the need to promote a specific culture that actively supports knowledge enhancement and awareness raising about DS among pharmacists. In return, this can significantly improve their decisions and the advice they give to consumers and help them make scientific evidence-based decisions systemically without the influence of other business-driven factors such as prices, brands or the availability of products. It is also recommended that community pharmacists incorporate learning about CAM into their continued professional development. Such learning can be a step in the right direction wherein knowledge and practices would not only be about herbal medicine but also DS.

\section{ACKNOWLEDGEMENT}

The authors would like to thank everyone who contributed to this study, especially by distributing, filling and collecting the questionnaires.

\section{CONFLICT OF INTEREST}

The authors declare no conflicts of interest.

\section{FUNDING}

No funding was received for this study.

\section{AUTHORS' CONTRIBUTION}

MA contributed in the concept and design, $\mathrm{MH}$ in writing the manuscript discussion and proving final draft, MB data analysis and interpretation and SA writing and proving final draft.

\section{References}

1. Weeden A, Remig V, Holcomb CA, Herald TJ, Baybutt RC. Vitamin and mineral supplements have a nutritionally significant impact on micronutrient intakes of older adults attending senior centers. J Nutr Elder 2010;29:41-54. https:// doi.org/10.1080/01639366.2010.480897.

2. Briefel R, Hanson C, Fox MK, Novak T, Ziegler P. Feeding infants and toddlers study: Do vitamin and mineral supplements contribute to nutrient adequacy or excess among US infants and toddlers? J Am Diet Assoc 2006; 106:52.e1- e15. https:// doi.org/10.1016/j.jada.2005.09.041.

3. Stang I, Story MT, Harnack L, Neumark-Sztainer D. Relationships between vitamin and mineral supplement use, dietary intake, and dietary adequacy among adolescents. J Am Diet Assoc 2000; 100:905-10. https://doi.org/10.1016/S00028223(00)00262-5.

4. Mason P. One is okay, more is better? Pharmacological aspects and safe limits of nutritional supplements. Proc Nutr Soc India 2007; 66:493-507. https://doi.org/10.1017/ S0029665107005812

5. Axon DR, Vanova J, Edel C, Slack M. Dietary supplement use, knowledge, and perceptions among student pharmacists. Am J Pharm Educ 2017; 81:1-12. https://doi.org/10.5688/ajpe81592. 
6. Balzo Vd, Vitiello V, Germani A, Donini LM, Poggiogalle E, Pinto A. A cross sectional survey on dietary supplements consumption among Italian teenagers. PLoS One 2014; 9:1-6. https://doi.org/10.1371/journal.pone.0100508.

7. Lentjes MA. The balance between food and dietary supplements in the general population. Proc Nutr Soc 2019; 78:97-109. https://doi.org/10.1017/S0029665118002525.

8. Blumberg JB, Frei BB, Fulgoni VL, Weaver CM, Zeisel $\mathrm{SH}$. Impact of frequency of multi-vitamin/multi-mineral supplement intake on nutritional adequacy and nutrient deficiencies in US adults. Nutrients 2017; 9:849. https://doi. org/10.3390/nu9080849.

9. Murphy SP, White KK, Park SY, Sharma S. Multivitaminmultimineral supplements' effect on total nutrient intake. Am J Clin Nutr 2007; 85:280S-4S. https://doi.org/10.1093/ ajen/85.1.280S.

10. Harrison RA, Holt D, Pattison DI, Elton PI. Are those in need taking dietary supplements? A survey of 21923 adults. Br J Nutr 2004; 91:617-23. https://doi.org/10.1079/BJN20031076.

11. Khatib LA, Obeid O, Sibai A-M, Batal M, Adra N, Hwalla N. Folate deficiency is associated with nutritional anaemia in Lebanese women of childbearing age. Public Health Nutr 2006; 9:921-7. https://doi.org/10.1017/phn2005921.

12. Bagchi K. Iron deficiency anaemia--an old enemy. East Mediterr Health J 2004; 10:754-60.

13. Hwalla N, Al Dhaheri AS, Radwan H, Alfawaz HA, Fouda MA, Al-Daghri NM, et al. The prevalence of micronutrient deficiencies and inadequacies in the Middle East and approaches to interventions. Nutrients 2017; 9:229.

14. Huang HY, Caballero B, Chang S, Alberg AJ, Semba RD, Schneyer C, et al. Multivitamin/Mineral supplements and prevention of chronic disease: executive summary. Am J Clin Nutr 2007; 85:265S-8S. https://doi.org/10.1093/ajcn/85.1.265S.

15. Parian A, Limketkai BN. Dietary supplement therapies for inflammatory bowel disease: Crohn's disease and ulcerative colitis. Curr Pharm Des 2016; 22:180-8. https://doi.org/10.21 74/1381612822666151112145033.

16. Asher GN, Corbett AH, Hawke RL. Common herbal dietary supplement-drug interactions. Am Fam Physician 2017; 96:101-7.

17. Amadi CN, Mgbahurike AA. Selected food/herb-drug interactions: Mechanisms and clinical relevance. Am J Ther 2018; 25:e423-e33. https://doi.org/10.1097/MJT.0000000000000705.

18. Alsayari A, Almghaslah D, Khaled A, Annadurai S, Alkhairy MA, Alqahtani HA, et al. Community Pharmacists' Knowledge, Attitudes, and Practice of Herbal Medicines in Asir Region, Kingdom of Saudi Arabia. Evid Based Complement Alternat Med. 2018; 2018:1568139. https://doi. org/10.1155/2018/1568139.

19. Shraim NY, Shawahna R, Sorady MA, Aiesh BM, Alashqar GS, Jitan RI, et al. Community pharmacist' knowledge, practices and beliefs about complementary and alternative medicine in Palestine: A cross-sectional study. BMC Complement Altern Med 2017; 17:429. https://doi.org/10.1186/s12906-017-1940-8.

20. Awaisu A, Kheir N, Ibrahim MIM, El-Hajj M, Hazi H, Khudair $\mathrm{N}$, et al. Knowledge, attitudes, and practices of community pharmacists on generic medicines in Qatar. Int J Clin Pharm 2014; 36:394-404. https://doi.org/10.1007/s11096-013-9909-2.

21. Shilbayeh SA. Exploring knowledge and attitudes towards counselling about vitamin supplements in Jordanian community pharmacies. Pharm Pract 2011; 9:242. https://doi. org/10.4321/S1886-36552011000400010.
22. Mehralian G, Yousefi N, Hashemian F, Maleksabet H. Knowledge, attitude and practice of pharmacists regarding dietary supplements: A community pharmacy-based survey in Tehran. Iran J Pharm Res 2014; 13:1457.

23. Zyoud S, Abd-Alhafez A, Hussein A, Abu-Shehab I, Al-Jabi S, Sweileh W. Patterns of use of medications, herbal products and nutritional supplements and polypharmacy associating factors in Palestinian geriatric patients. Eur Geriatr Med 2014; 5:188-94. https://doi.org/10.1016/j.eurger.2013.11.004.

24. Shields KM, McQueen CE, Bryant PJ. Natural product education in schools of pharmacy in the United States. Am J Pharm Edu 2003; 67:43-8. https://doi.org/10.5688/aj670110.

25. Emiru YK, Belay YB, Bizuneh GK, Tegegn HG. Community pharmacists' knowledge, attitude, and professional practice behaviors towards dietary supplements: Results from multicenter survey in Ethiopia. Nutr Diet Suppl 2019; 11:59-68. https://doi.org/10.2147/NDS.S222114.

26. Ministry of Health, Health Annual Report, Palestine 2020. 2021. From: https://www.unrwa.org/2020UNRWAHealthAnnu alReport Accessed: Sept 2020.

27. Field A. Discovering Statistics using SPSS (Introducing Statistical Methods Series) 3rd ed. Thousand Oaks, California, USA: Sage Publications Inc; 2009.

28. Howard N, Tsourounis C, Kapusnik-Uner J. Dietary supplement survey of pharmacists: Personal and professional practices. J Altern Complement Med 2001; 7:667-80. https:// doi.org/10.1089/10755530152755225.

29. Sasanfar B, Toorang F, Nemati S, Djazayery A, Zendehdel K. Development and validation of a knowledge, attitude, and practice questionnaire on nutrition-related cancer prevention for Iranian women. J Res Med Sci 2019; 24:87. https://doi. org/10.4103/jrms.JRMS_777_18.

30. Kwan D, Hirschkorn K, Boon H. US and Canadian pharmacists' attitudes, knowledge, and professional practice behaviors toward dietary supplements: A systematic review. BMC Complement Altern Med 2006; 6:31. https://doi.org/10.1186/1472-6882-6-31.

31. Holick MF, Biancuzzo RM, Chen TC, Klein EK, Young A, Bibuld D, et al. Vitamin D2 is as effective as vitamin D3 in maintaining circulating concentrations of 25-hydroxyvitamin D. J Clin Endocrinol Metab 2008; 93:677-81. https://doi. org/10.1210/jc.2007-2308.

32. Sharma A, Adiga S. Knowledge, attitude and practices related to dietary supplements and micronutrients in health sciences students. J Clin Diagn Res 2014; 8:HC10-HC13. https://doi. org/10.7860/JCDR/2014/9329.4683.

33. Woodside JV, McCall D, McGartland C, Young IS. Micronutrients: Dietary intake v. supplement use. Proc Nutr Soc India 2005; 64:543-53. https://doi.org/10.1079/PNS2005464.

34. Teng CL, Tey KK, Lim PH, Cheng SF, Nordin MS, Ng CM, et al. Dietary supplements: Usage and opinions among health sciences students. Int e-J Sci Med Edu 2008; 2:30-2.

35. Spencer EH, Bendich A, Frank E. Vitamin and mineral supplement use among US medical students: A longitudinal study. J Am Diet Assoc 2006; 106:1975-83. https://doi. org/10.1016/j.jada.2006.09.003.

36. Medhat M, Sabry N, Ashoush N. Knowledge, attitude and practice of community pharmacists towards nutrition counseling. Int J Clin Pharm 2020; 42:1456-68. https://doi. org/10.1007/s11096-020-01106-0. 